\title{
L'interés de Gaspar Escolano per la llengua i la literatura medievals i per Ramon Llull, a la Década primera de la historia de Valencia (1610)
}

\author{
The interest of Gaspar Escolano in medieval language and literature and \\ in Ramon Llull, in the Década primera de la bistoria de Valencia (1610)
}

\author{
Laura RomÀ HerÈdia \\ laurarh14@hotmail.com \\ Universitat de València
}

Resum: El present treball fa una aproximació a una obra clàssica de la historiografia valenciana al segle XVII, la Década primera de la insigne i coronada ciudad i reyno de Valencia (València 1610), de Gaspar Escolano, per tal de fixar-nos en l'interès d'aquest cronista en alguns dels autors medievals catalans. En especial, en Jaume I -en tant que fundador del Regne de València-, però també en Jordi de Sant Jordi, Andreu Febrer, Jaume Roig i, en especial, Ramon Llull, al qual dedica diversos capítols.

Paraules clau: Gaspar Escolano; medievalisme; barroc; clàssics medievals; Ramon Llull

Abstract: This work is an approach to a classic of historiography of València in the XVII century, Década primera de la insigne i coronada ciudad i reyno de Valencia (València 1610), of Gaspar Escolano, looking in the interest of the chronicler in Catalan medieval authors. Especially in Jaume I -like a founder of the Regne de València- and also in Jordi de Sant Jordi, Andreu Febrer, Jaume Roig and Ramon Llull to which devotes several chapters.

Keywords: Gaspar Escolano; medievalism; Baroque; medieval classics; Ramon Llull 
Laura Romà Herèdia. L'interés de Gaspar Escolano per la llengua i la literatura medievals i per Ramon Llull, a la Década primera de la historia de Valencia (1610)

\section{Introducció}

Per a l'elaboració d'aquest article ens hem endinsat en la crònica del valencià Gaspar Escolano, del 1610, Década primera de la historia de la insigne i coronada ciudad y reyno de Valencia i, hem observat la visió que té l'autor, del segle XVII, sobre el món medieval i la societat que l'envolta, destacant en tot moment la figura del rei Jaume i i el paper de la noblesa i les institucions que estan al capdavant del poder i l'odre del regne. Mostrant constantment la gran importància que tenen -per la posició de l'autor en la societat- la monarquia i les institucions religioses.

A més, hem fet un repàs pels autors valencians destacats en l'obra com són Jordi de Sant Jordi, Andreu Febrer, Ausiàs March, Jaume Roig o Sant Vicent Ferrer, als quals fa referència per enaltir la llengua que es parlava a la València del segles XVI i XVII i, en especial a Ramon Llull -a qui Escolano dedica diversos capítols.

Pel que fa al mallorquí, hem pretés analitzar quina visió se'n tenia d'ell en l'època d'Escolano i quin era l'interés que es tenia a la València d'aquells segles, portant a terme prèviament, és clar, l'edició dels capítols de la crònica on s'hi tracta el tema.

\section{La visió de Gaspar Escolano sobre la història i la cultura medievals}

\subsection{Gaspar Escolano: sacerdot $i$ bistoriador}

Gaspar Joan Escolano va nàixer el 1560 a la ciutat de València i fou batejat el 4 de gener d'aquest mateix any, a l'església parroquial de sant Martí. Els seus pares van ser Gaspar Escolano, comissari reial, membre del consell de la ciutat de València i persona que participà la tasca de desarmar els moriscos revoltats a la Vall de Gallinera el 1563; i de Francesca Villalba, natural de València (Martí Grajales 1892: 9).

Escolano -suposadament, ja que no s'ha pogut demostrar amb certesa- realitzà els estudis de Teologia a la Universitat de València i va obtenir els títols de llicenciat i doctor en aquesta matèria. El 15 de gener de 1592 passà a formar part de l'Acadèmia dels Nocturns -institució literària fundada pel noble Bernat Guillem Català de Valleriola (1591-1594)-, i allà va fer servir el pseudònim de «Luz». Això li va permetre establir contacte amb altres autors de major prestigi, com Francesc Agustí Tàrrega, Gaspar Aguilar, Miquel Beneito i altres. El fet que no ens hagen pervingut obres d'Escolano d'abans de ingressar a l'Acadèmia ens fa pensar que, o bé es van perdre, o bé la seua difusió fou ben escassa, com és el cas de l'obra escrita el 1588, Libelli duo, que restà inèdita; o també el sonet laudatori escrit per a una hagiografia sobre sant Tomàs de Villanueva -apareix als preliminars de l'obra- de Miquel Salom (1588), catedràtic de teologia de la Universitat de València. Per altra banda, convé assenyalar que de les intervencions d'Escolano a les reunions de l'Acadèmia dels Nocturns, ens han arribat solament cinc discursos, que s'han conservat als llibres d'actes d'aquesta, actualment a la Biblioteca Nacional de Madrid, tot i que ja han estat publicats convenientment, junt a la resta dels materials del cenacle literari dels Nocturns (Martí Grajales 1892: 9).

SCRIPTA, Revista internacional de literatura i cultura medieval i moderna, núm. 4 / desembre 2014 / pp. 68 - 79 ISSN: 2340-4841 $\cdot$ doi:10.7203/SCRIPTA.4.4486 
Laura Romà Herèdia. L'interés de Gaspar Escolano per la llengua i la literatura medievals i per Ramon Llull, a la Década primera de la historia de Valencia (1610)

Al marge d'aquella activitat literària, ens consta que el 28 de febrer de 1597, Gaspar Joan Escolano va ser nomenat rector de la parròquia de Sant Esteve Protomàrtir, de València, passant així a ocupar el càrrec que exercí fins la seua mort.

El 1600 amb motiu de l'arribada d'una relíquia de sant Vicent Ferrer a la ciutat de València, Escolano participà en la justa poètica que es va celebrar (Ferrando 1983). A més, també, el trobem participant en altres certàmens d'aquesta mateixa època, organitzats pel que havia estat president i fundador de l'Acadèmia dels Nocturns, el noble Català de Valleriola. En aquestes vel leïtats poètiques d'Escolano primava sobretot el seu desig de mostrar la seua devoció, i renunciava d'antuvi a qualsevol premi ofert (Martí Grajales 1892: 9).

El 13 d'abril de 1602, el teòleg i matemàtic Pere Joan Monsó, predicador de la ciutat de València, per causes de salut degudes a la seva avançada edat, escollí a Escolano per substituir-lo i, quatre anys després, el 15 de març de 1606, amb la mort de Monsó, Gaspar Joan Escolano va ser designat com a predicador municipal, càrrec que confirmà el consell de la ciutat amb el nomenament oficial, el 22 de desembre d'aquest mateix any (Martí Grajales 1892: 10). Això, en definitiva, el facultava per predicar, representant el poder local, en les principals festes de la ciutat, com ara les de sant Vicent, sant Jordi, sant Donís -el 9 d'octubre-, i d'altres en què era necessari usar el català preceptivament, com es veu clarament a l'obra del preceptista Joan Baptista de Valda (1998).

En un altre ordre de coses, sabem que Escolano era avesat als estudis històrics, fet que el va fer ocupar-se durant molts anys a recollir documentació i informació sobre el regne de València, amb la intenció de poder redactar una obra que recollís la història completa d'aquest. Així doncs, el 1604, reunides les Corts valencianes pel rei, presentà tota aquesta documentació aplegada i, a tenor del seu treball, se li va concedir el títol de cronista del regne de València, comprometent-se la Generalitat, i amb l'aprovació del monarca, el 1605, a costejar les despeses de la impressió de la futura crònica del país que Escolano s'obligava a redactar (Martí Grajales 1892: 10).

D'aquella manera, com veurem, els seus escrits adquiririen un prestigi d'oficialitat que el va fer guanyar en relleu davant els seus contemporanis, que el contemplaven com un home erudit i assenyat, al qual se li confiaren importants decisions i negocis, fins el punt de nomenar-lo secretari de la junta de teòlegs, executada el 1608, amb el motiu d'aconsellar Felip III sobre la conveniència de l'expulsió dels moriscos de terres hispàniques i que tingué un paper molt important en el posterior decret que posà fi a la presència d'aquella minoria ètnica i religiosa al País Valencià (Escartí 2009: 15-17).

Entre els anys 1610 i 1611, i una vegada enllestits els seus treballs per redactar la crònica -segurament precipitats per la recentíssima expulsió dels moriscos, que era vista com un esdeveniment històric destacable (Escartí, 2009 15-17)-, es portà a termini la publicació de la Década primera de la historia de Valencia, dividida en dos volude 5 llibres cadascun, la qual comprén des dels orígens més remots de les terres hispàniques, tal com venia sent habitual d'ençà Beuter (Escartí 1998), abans del diluvi universal, fins al regnat de Pere III, el Gran. Tanmateix, Escolano reservà el desé llibre a dos temes concrets, com són les Germanies i l'expulsió dels moriscos, de més actualitat en l'època de l'autor.

SCRIPTA, Revista internacional de literatura i cultura medieval i moderna, núm. 4 / desembre 2014 / pp. 68 - 79 ISSN: 2340-4841 $\cdot$ doi:10.7203/SCRIPTA.4.4486 
Laura Romà Herèdia. L'interés de Gaspar Escolano per la llengua i la literatura medievals i per Ramon Llull, a la Década primera de la historia de Valencia (1610)

Amb la publicació d'aquesta primera part de les Décadas de la historia de la insigne y coronada ciudady Reino de Valencia anuncià la seua pretensió de publicar la Década segunda, que abraçaria des del regnat d'Alfons el Franc fins l'època dels Reis Catòlics, obra que a la fi no arribà a veure la llum i de la qual no resta constància escrita, tot i que, ja al segle XIX, Joan Baptista Perales completaria els escrits d'Escolano en portar avant una nova edició de l'obra de l'erudit, que ja seria publicada a Madrid, amb afegits, adaptacions en les grafies i l'allargament del discurs històric fins als mateixos temps de Perales (Belenguer 2009: 121-127).

Finalment, l'any 1616, Escolano publicà la que seria la seua darrera obra, Omnium decretorum quae in Valentinis synodis statuta sunt [...], de caire religiós i erudit. Gaspar Joan Escolano moria el 20 de febrer de 1619, amb cinquanta nou anys d'edat, deixant, però, una de les obres que estava destinada a tenir una gran fortuna entre els erudits i estudiosos valencians, atés que el seu treball ha estat usat i citat molt sovint.

\subsection{L'interés de Gaspar Escolano pel món medieval}

A la Década primera de la historia de la insigne y coronada ciudad y reyno de Valencia (València, Pere Patrici Mey, 1610) la presència de l'època medieval és més que considerable, malgrat que l'autor no va optar per articular-la sempre de manera cronològica i, tampoc, va considerar el món medieval com un argument diferent de la història.

Per poder analitzar la visió que tenia Escolano del món medieval, o els interessos que mostra sobre aquest, a la seua crònica, hem de situar-nos en el seu context, atés que Escolano viu a la València de finals del segle XVI i principis del segle XVII, una València que ha perdut l'hegemonia econòmica, que es troba immersa en l'època de l'absolutisme monàrquic $\mathrm{i}$ amb una societat encara senyorial, i que, refeta del daltabaix de les Germanies -als anys 20 del segle XVI-, estava destinada a patir el sotrac de l'expulsió dels moriscos que, per damunt de la ideologia religiosa unitarista que comporta, suposà un colp econòmic per al país (Escartí 2009: 11-12). Per altra banda, com és ben sabut, aquella societat barroca serà la mostra més exacerbada del fervor i de les celebracions religioses, a nivell públic (Maravall 1981). Per una altra banda, hem de recordar també la posició d'Escolano, dins d'aquesta societat: era fill d'un comissari reial i membre de Consell de sa majestat; amb formació religiosa, doctor en teologia, rector d'una parròquia important i exercint el càrrec de predicador de la ciutat, a més d'home de confiança per a assumptes polítics de relleu i secretari en la darrera junta que decidí l'expulsió dels moriscos, com ja hem esmentat.

Totes aquestes dades, sens dubte havien de pesar en la configuració de la visió del món d'Escolano i, per altra banda, en la seua mirada cap al passat, cap al món medieval que segurament era vist amb una evident veneració i que, d'alguna forma, era proposat com a model sociopolític per part dels intel lectuals locals. I bastarà només un exemple: quan Bernardí Gómez Miedes -contemporani d'Escolano- realitzarà les seues paràfrasis del Llibre dels feits -en llatí, el 1582, i en castellà el 1584-i 
Laura Romà Herèdia. L'interés de Gaspar Escolano per la llengua i la literatura medievals i per Ramon Llull, a la Década primera de la bistoria de Valencia (1610)

les regalarà a la casa reial, estarà, en definitiva, proposant un model de monarca medieval als reis de l'Espanya dels Àustries (Escartí 2012). D’això, se'n dirà cesarisme, però el model reial es trobarà ubicat a l'edat mitjana.

Com bé afirma Pau Viciano (2000: 135-150), «la crònica de Gaspar Escolano [...] ofereix una lectura del passat medieval del País Valencià sense ruptures amb el seu propi present». És així com Escolano, al llarg de l'obra, mostra interés pels fets medievals, per demostrar la importància d'aquests en la formació del regne de València, basant-se en temes com l'origen "nacional" dels valencians, la qüestió morisca, la noblesa i el poder del regne i de la societat.

Corroborem les afirmacions de Pau Viciano, en adonar-nos com Escolano lliga el seu món present als esdeveniments del món medieval, per trobar-hi, sovint, una explicació. Això es veu clarament al llarg de la seua crònica, on l'esdeveniment que sembla més important per a l'autor és la conquesta de València per part de Jaume I i el regnat d'aquell, ja que representarà un renàixer del regne on s'hi forma la identitat d'aquest i que reprén, després de l'arribada dels visigots i la posterior conquesta musulmana, la cristianització. De fet, amb la conquesta jaumina, Escolano sabia que s’iniciava una nova etapa per a les terres valencianes, una nova etapa que, per l'afany dels humanistes hispànics de superar la tradició llatina clàssica, volien enllaçar amb els gots i encara més enrere, en una recerca impossible de les arrels mítiques de la Hispània preromana (Duran 1991: 246-247). Escolano, malgrat titular la seua crònica amb la referència general a la història de la insigne y coronada ciudad y reyno de Valencia, no és fins l'arribada del rei Jaume I quan realment s'ajusta als esdeveniments d'aquest territori, ja que, per al seu objectiu d'explicar la identitat del poble del regne de València, no podien entrar al joc els musulmans ni els anteriors habitants, que no havien de formar part d'aquest esglaó i amb els quals no volia tenir trets en comú, més enllà d'uns hipotètics nexes d'unió que venien donats pel fet d'haver habitat unes mateixes terres. Així, fins que no es dóna la fragmentació musulmana en taifes, Escolano descriu a la seua crònica la visió d'un espai més ampli, que engloba tota la península; i és amb la fragmentació musulmana, que va acostant-se al territori pròpiament valencià (II, cap. XIX), però encara de lluny. Tanmateix, Escolano se sap descendent d'una altra tradició, i és per això que decideix oferir-nos els esdeveniments des de la resistència pirinenca, amb els cristians del nord, que, per a Escolano, són els seus vertaders avantpassats. Però, des d'aquest moment, no deixa de tenir com a objectiu el territori valencià, encara que això no l'impedeix de mostrar-nos tant l'evolució dels musulmans a València com la dels regnes cristians del nord, fins a la decisiva conquesta catalanoaragonesa, on ja fixa el seu objectiu en el País Valencià estrictament (II, cap. XVI).

La conquesta de València per part de Jaume I no significava només un èxit militar front als musulmans, per a Escolano, sinó un canvi ètnic, polític i lingüístic que afermava el regne de València com a entitat pròpia i autònoma dins la Corona d'Aragó. L'autor reconeix els lligams dels valencians amb els catalans, que formaven la gran majoria de repobladors, però quan tracta aquest tema no ho fa per agermanar-se amb la cultura catalana, sinó que ens mostra com, partint d'una base de

SCRIPTA, Revista internacional de literatura i cultura medieval i moderna, núm. 4 / desembre 2014 / pp. 68 - 79 ISSN: 2340-4841 · doi:10.7203/SCRIPTA.4.4486 
Laura Romà Herèdia. L'interés de Gaspar Escolano per la llengua i la literatura medievals i per Ramon Llull, a la Década primera de la bistoria de Valencia (1610)

repobladors catalans, ha esdevingut una identitat clarament nova, amb una llengua també pròpia -que ha superat la catalana- i unes lleis i maneres de fer pròpies (I, cap. XIV). Admet que la llengua deriva del català, però destaca la valenciana com a més gloriosa i elaborada per distingir-la de la dels catalans. Amb tot, les pretensions del cronista no es basen en diferenciar-se dels catalans, sinó en dotar el seu regne d'autonomia i importància individual i de refermar-se front a l'hegemonia dels castellans i la pretensió de predomini de Castella. (III, cap XXII) Ara bé, com podem entendre pel paper que jugava Escolano en l'època, al servei del poble i de les autoritats, com a autoritat mateixa, no mostrava cap rebuig a la monarquia hispànica ni qüestionava la seua fidelitat, el que pretenia era demostrar que una cosa no impedia l'altra i que, a pesar d'estar tots englobats dins d'un mateix nom, dins d'una mateixa unió d'Espanya, havia de ser compatible el fet de reconéixer el regne de València com una nació amb furs propis i amb identitat ben diferenciada (I, cap XV).

Seguint aquest mateix propòsit, Escolano s'aferra a una altra font per demostrar la legitimitat de la seua proposta de nació valenciana amb pes i identitat pròpia: els llinatges. Pretén demostrar els orígens de tots aquells cognoms aristocràtics, de la noblesa que, en l'època moderna, compta amb una posició destacada, al costat de l'estament eclesiàstic i la monarquia. Per dur a terme aquesta tasca, l'autor no dedica cap dels volums concretament a la genealogia dels llinatges, sinó que els lliga a la descripció geogràfica que va realitzant des del sisé fins el nové llibre de les Décadas i seguint el criteri de les possessions que pertanyen a aquestes famílies, al segles XVI i XVII, manera, alhora, de ratificar-les i corroborar-les,

«Arnaldo Lansol tuvo el cargo de jurado por el estamento de los cavalleros [...] mereció que el rey Don Pedro el Quarto de Aragón le hiziese merced de toda jurisdicción en la valle de Villalonga, por haverle servido con dos galeras en la jornada contra Abul Melich, rey moro de Marruecos». (IX, cap. XLVI, pàg. 1394)

Generalment, quan parla de famílies d'arrel catalana o aragonesa, les lliga a la lluita contra l'islam, duta a terme amb la conquesta jaumina, al servei de la corona. Quan tractava sobre llinatges, els orígens dels quals no podia lligar amb les dades de la conquesta, remetia a un passat més llunyà, als segles VII i IX, enllaçant-los amb la monarquia dels cristians del nord, dels Pirineus, amb els comtes d'Aragó o els avantpassats d'aquests que són, segons Escolano, els reis del Sobrarb i la Ribagorça. $\mathrm{O}$ anava més enllà, a territori francés, per enllaçar-los amb cases reials, com fa amb els Boils; o, fins Hongria, per fer-los descendir dels seus reis, que posteriorment arribaren a Catalunya, de la mà de l'emperador Carlemany,

Su venida d'ellos a Cataluña, fue con el emperador Carlo Magno. Y según lo canta un manuscripto antiguísimo que tengo en mi librería, de la división de aquel Principado, hecha por el Emperador (o por lo menos recopilada, de muchos años atrás, por algún curioso catalán) en Vizcondados, Baronías, Veguerías y casas solariegas en cada Veguería; los Vilaragudes fueron heredados en el districto del condado que agora es de Osona: y entre treynta y dos Baronías que quedaron fundadas, hallamos haverles cabido dos, la una con título de Baronía de Vilaragud de Sobirats; y la otra, de Vilaragud de San Martín de So. (VIII, cap. XvII, pàg.840)

SCRIPTA, Revista internacional de literatura i cultura medieval i moderna, núm. 4 / desembre 2014 / pp. 68 - 79 ISSN: 2340-4841 · doi:10.7203/SCRIPTA.4.4486 
Laura Romà Herèdia. L'interés de Gaspar Escolano per la llengua i la literatura medievals i per Ramon Llull, a la Década primera de la bistoria de Valencia (1610)

Si, a més, no aconseguia enllaçar famílies directament amb les cases reials, les associava a la figura del ja esmentat Carlemany o a la conquesta de l'imperi franc al Principat.

Però l'esforç d'Escolano per ennoblir els llinatges no acabava ací. També trobava parentescos entre cognoms com els dels Anglesola, Aguiló, els Català o els Montcada, a través de la llegenda d'Otger Cataló, amb ell mateix -com és el cas dels Català-o amb els nou cavallers que -suposadamentl'acompanyaven, deixant de banda els fets més propers al seu temps i endinsant-se en elements ara mítics,

En el libro primero, capítulo diez y siete, dexamos asentado, que en la recuperación de Cataluña, después de la entrada de los moros en España, se halló Auger de Catalón con nueve capitanes que le siguieron; de los quales era el primero y mas principal Dapifec o Napifer de Montcada, como se parece en que muerto Auger, le sucedió en el govierno y cargo de General (VIII, cap XxIII, pàg.891).

Tan mítics que, una altra de les fonts per emparentar llinatges arribava fins a l'Antiguitat romana, que gaudia de gran valor a l'època moderna i així revaloritzava encara més els cognoms lligats a ella, com era el cas dels Cornell o els Pardo, «Nuestro Beuter certifica que de los Romanos quedaron por aca dos linages principales entre otros muchos; que fueron los Cornelios, que agora corrompidamente llamamos Corneles; y los Pardos» (VI, cap. XI, pàg. 87), admetent fabulacions que en la major part dels casos no tenien cap fonament real.

Per poder mostrar la certesa de les seues afirmacions, més fàcils de demostrar amb els llinatges lligats a la conquesta jaumina per l'existència de documentació, Escolano havia de recórrer a fonts com la Crònica de Beuter (Escartí 1998), per dotar de gran credibilitat les fonts llegendàries o a afirmar que aquestes afirmacions havien estat extretes de manuscrits existents i que havien arribat a les seues mans, com en el cas abans citat del cognom Vilaragud.

En definitiva, i sabent la posició d'Escolano en l'entramat social del seu temps, no se'ns fa estrany veure el propòsit de l'autor, quan pretén de legitimar aquests llinatges i dotar-los de gran valor, mitjançant els parentescos amb la reialesa o l'antiguitat, atés que eren els qui dominaven, amb la seua condició de noblesa, en l'època del cronista, i és per això que ell mateix tractava de reforçar el seu poder i prestigi.

Per últim, referint-nos a la visió que presenta Escolano del món medieval en la seua obra, no podem deixar de banda, malgrat que no li dedicarem massa espai, el fragment dedicat a les institucions i al poder. Així, al XXV capítol del llibre cinqué, De regimiento, regidores y forma de república de la ciudady reyno de Valencia, (pàg. 1076-1090) Escolano fa una relació de totes les institucions i càrrecs públics del regne valencià medieval i foral, relacionant-les amb el seu origen en el temps jaumí. Però no sols això, sinó que enceta aquest llistat amb les institucions eclesiàstiques, com la inquisició, de gran importància per a ell, i així arriba a dir: «En lo espiritual, generalmente se govierna por los perlados: y en las causas de la fe, por el Tribunal del Santo Oficio de la Inquisición, cuyo districto se estiende 
Laura Romà Herèdia. L'interés de Gaspar Escolano per la llengua i la literatura medievals i per Ramon Llull, a la Década primera de la bistoria de Valencia (1610)

a los obispados de Segorve, Albarrazín y Tortosa» (pàg.1077). També, i una vegada més, engrandint el paper de l'aristocràcia i la noblesa, es mostra orgullós de que siguen aquests els qui exerceixen el poder institucional al costat de la corona, ja que per a l'autor, no està bé deixar-ho a mans de mercaders o gent d'oficis, que puguen posar en perill el bé comú, «Acertada resolución fue la de nuestros legisladores, en no acoger a cargo tan importante, mercaderes, ni hombres mecánicos que biven de sus manos» (pàg. 1082). Per tant, quant a aquest tema, no fa altra cosa que remarcar l'ordre que s'obté amb l'equilibri entre les institucions, la corona i el bon ús de les lleis, «Ya es tiempo que tratemos del govierno de la República de Valencia [...] según que es maravilloso el concierto político de su govierno. Éste participa de República libre, y de subdita a su rey y señon» (pàg. 1077) i girant la mirada de nou a l'època medieval, observem com Escolano fa un especial esment al paper dels reis Jaume I, amb la creació dels furs, i el seu fill Pere, que a ulls d'Escolano són els «factors» del regne valencià, «Luego el primero de Deziembre celebró las cortes, en que mejoró, y declaró los fueros que el rey su padre havia dado al nuevo reyno, y añadió muchos de grande importancia, para la acertada dirección de la República» (III, cap. XV, pàg. 586).

En conclusió, a través d'aquesta aproximació que fa Escolano al món medieval, podrem dir que el nostre autor era fill de la seua època, un home lligat a l'església i al poder públic, nodrit i crescut en aquests àmbits, i que no podia tenir una altra visió del món que la configurada per aquests elements, un home que en els seus escrits, en la seua crònica exalta clarament el paper de la corona i dels seus representants -als quals serveix i que són els qui paguen l'edició de les Décadas- i que tracta d'establir una identitat col lectiva basada en el les arrels de la noblesa, que reafirma el paper de l'església i justifica contínuament i durant tota l'obra la lluita contra els moriscos -que tot just acabaven de ser expulsats- (Escartí 2009: 16-17), i qualsevol altre perill que puga fer tremir els pilars de la seua nació.

\section{Escolano i la tradició literària en català}

Com ja hem esmentat amb anterioritat, una de les qüestions que tractava Escolano en la seua crònica, per defensar la seua idea de "nació" amb identitat pròpia, era la de la llengua pròpia dels valencians. Així doncs, la llengua representava per a Escolano un pilar fonamental per reforçar la seua tesi i posicionar-se contra la idea d'hegemonia i predomini dels castellans. Per això, n'explicarà els seus orígens i, també, esmentarà els autors valencians més il lustres que l'havien representada.

Aquest tema ens el presenta al capítol XIV del llibre primer de la primera part de les Décadas, sota el títol De la lengua lemosina y valenciana (pàg. 88-97). Així doncs, en referir-se a la llengua dels valencians, inicia el capítol parlant de la llengua llemosina i dels seus orígens,

La tercera y última lengua maestra de las de España, es la lemosina y más general que todas después de la castellana, por ser la que se hablava en la Proença y toda la Guiayna y la Francia gótica, y la que agora se babla en el principato de Cataluña, reino de Valencia, islas de Mallorca, Menorca, Yviça y Sardeña. Tuvo

SCRIPTA, Revista internacional de literatura i cultura medieval i moderna, núm. 4 / desembre 2014 / pp. 68 - 79 ISSN: 2340-4841 · doi:10.7203/SCRIPTA.4.4486 
Laura Romà Herèdia. L'interés de Gaspar Escolano per la llengua i la literatura medievals i per Ramon Llull, a la Década primera de la historia de Valencia (1610)

\begin{abstract}
esta lengua su nacimiento y nombre de una ciudad de Francia que en tiempo de romanos fue llamada Lemonices y en el nuestro Limoges, y la provincia Limós. Formóse del ayuntamiento de la que pasaron consigo los españoles, al tiempo de los moros y de la francesa que por allá corría. D'estas dos fue engendrada y nació tan graciosa, cortesana, sentenciosa y dulce, que no hay lengua que en más breves palabras diga más ni mejores conceptos, teniendo en todo una biva semejança con su madre la latina.
\end{abstract}

D'aquest paràgraf convé assenyalar com Escolano admet la unitat de la llengua -des del Principat fins a Sardenya- i, per una altra banda, cal remarcar com l'autor no vol admetre un origen francés per a la nostra llengua i és per això que assenyala com hi havien participat, en la seua construcció, «els españoles» que s'havien refugiat allà, «al tiempo de los moros».

A més, afirma que «nuestros proençales lemosines» són els primers a fer versos, els pares de la poesia «vulgar» $\mathrm{i}$ dels quals, posteriorment copiaren els sicilians pel contacte entre aquestos i els reis d'Aragó o els francesos, i que desembocaren a Itàlia. D'aquesta manera, pretén demostrar - encetant la relació d'autors valencians- com Petrarca va copiar versos a «mossén Jordi», el qual identifiquem amb Jordi de Sant Jordi, cosa que, com sabem, ja ho havia remarcat la Crònica de Beuter (Escartí 1998).

Així, Escolano ens el presenta com a mossén Jordi i diu -erròniament- que cap a l'any 1250 visqué a la ciutat de València i fou un famós cavaller i poeta, criat a la cort del rei Jaume I -recordem la importància de la figura del rei per a Escolano- que escrivia sonets, sextils, tercets i octaves rimes en valencià «llemosí». Per verificar la certesa de les seves afirmacions, l'autor cita un fragment de Jordi de Sant Jordi i el compara amb un de Petrarca (I, cap. XIV pàg. 90).

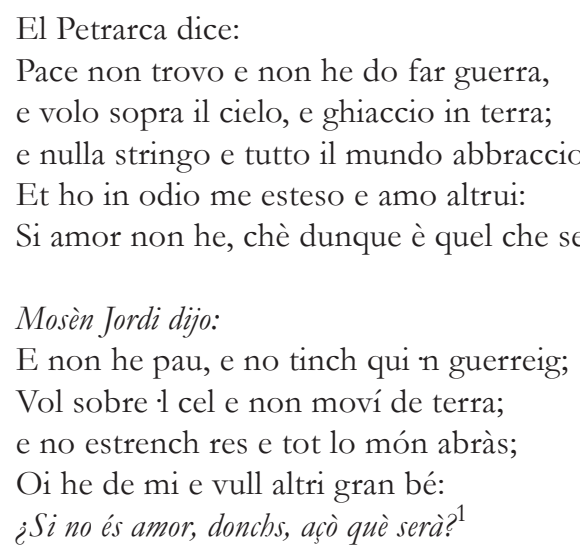

Evidentment, Escolano tractava de potenciar la tradició valenciana i ibèrica per damunt de la italiana, un aspecte que havia estat ja assumit en camps com la historiografia (Duran 1991). Però, per finalitzar amb la figura de Jordi de Sant Jordi, Escolano argumenta novament la teoria del plagi de Petrarca explicant-nos com varen poder arribar els escrits del dit mossén Jordi a les mans de l'autor italià, basant-se en el que diu Beuter a la seua crònica,

1 El fragment en italià prové del Cançoner de Petrarca (Cortines 1989). Per altra banda, el text català és de Jordi de Sant Jordi, i forma part de la Cançó d'opòsits (Riquer/Badia 1984: 219-230)

SCRIPTA, Revista internacional de literatura i cultura medieval i moderna, núm. 4 / desembre 2014 / pp. 68 - 79 
Laura Romà Herèdia. L'interés de Gaspar Escolano per la llengua i la literatura medievals i per Ramon Llull, a la Década primera de la bistoria de Valencia (1610)

\begin{abstract}
hallándose en Gascuña con don Jaime Colona, obispo de Lumbierri, en tiempo del papa Juan XXIII, como llegase a las rayzes de los Pyrineos [...] pudieron venir a sus codiciosos ojos, como tentados de aquel manjar, las rimas del dicho cavallero que ya entonces corrían por Cataluña y Gascuña con gran renombre de su autor; y entonces le desentrañó el estilo, las agudezas, ternuras y conceptos, pasándolo a su proposito y lengua. (I, cap xiv, pàg. 90-91)
\end{abstract}

Tot seguit, Escolano parla d'un altre dels autors valencians de renom, dins la tradició literària catalana: mossén Febrer, a qui identifiquem amb el poeta Andreu Febrer. D'aquest diu que és contemporani de mossén Jordi -Jordi de Sant Jordi- i que escrigué sonets sobre «la tormenta que corrió el rey don Jayme enfrente de Mallorca, el año susodicho de mil doscientos y cincuenta, o poco más, navegando con su armada a la conquista de la tierra Santa» (I, cap. XIV pàg. 91), (Febrer $1951)^{2}$. Aquests fets, afirma Escolano, demostren com eren d'antigues les composicions llemosines i com de valuoses i prestigioses, tant elles com la llengua, pels temes que es tractaven amb gran dignitat.

Pel que fa a les característiques i virtuts de la llengua i del seu ús, ja citades anteriorment, Escolano pretén demostrar-les mitjançant anècdotes de traducció d'obres d'autors valencians -continuant així amb la relació de noms de poetes importants. Explica que, per a traduir un vers llatí, se'n necessiten dos i tres versos en castellà $i$ que de la mateixa manera els passa als versos en la nostra llengua. Ara, fa referència a les codolades -o cudolades, segons Escolano- escrites en «llemosí» per Jaume Roig: «aquel su memorable libro contra las mujeres, intitulado de Consejos» que, com indica la citació del titol, Escolano devia de conéixer per l'edició valenciana del segle XVI (1a. ed.: València 1531) ${ }^{3}$ i que, en opinió de l'autor, mai s'haurien pogut traduir exitosament al castellà. Així com els versos d'un altre «profundísimo poeta valenciano»: Ausiàs March, que havia temptat de traduir el portugués Jorge de Montemayor, del qual diu que «puso con grande cuidado la mano en la labor, traduciendo en castellano sus obras escritas con tanta pujanza de conceptos en lemosín» però que, comparantlos amb els de l'autor valencià, semblaven dues obres diferents (Escartí 1997).

Escolano, reprén de nou les explicacions sobre els orígens de la llengua, però ara amb un propòsit diferent al de l'inici. Ara ho fa per destacar la variant valenciana de la llengua que considera superior a la catalana. L'autor reconeix els seus orígens paral lels i fins i tot reconeix que la valenciana prové de la catalana, però, alhora, ens dóna una sèrie d'arguments per diferenciar-les i diu que,

Esta lengua se començó a hablar en la ciudad y reyno de Valencia, y con el curso del tiempo, se fue adelgazando de suerte que, arrimando algunos vocablos groseros que hoy en día se quedan en la catalana $[\ldots]$ ha venido a tener nombre de por sí y llamarse lengua valenciana (pàg. 92-93).

\footnotetext{
2 Fa referència al Sirventesch per lo passatge de Barbaria d'Andreu Febrer, cançó de croada feta per a encoratjar els cavallers cap a la lluita contra els infidels al nord d’Àfrica.

3 Es tracta de l'edició de l'obra de Jaume Roig que porta per títol Llibre de les dones: més verament dit de consells profitosos y saludables, aixi per al regiment y ordre de la vida bumana com per a aumentar la devoció de la immaculada concepció de la sacratíssima verge Maria, publicada a València, per Joan d'Arcos, el 1531.
}

SCRIPTA, Revista internacional de literatura i cultura medieval i moderna, núm. 4 / desembre 2014 / pp. 68 - 79 ISSN: 2340-4841 · doi:10.7203/SCRIPTA.4.4486 
Laura Romà Herèdia. L'interés de Gaspar Escolano per la llengua i la literatura medievals i per Ramon Llull, a la Década primera de la bistoria de Valencia (1610)

Afirma que la llengua que es parla al regne de València està més polida i és més cortesana, que s'entén en els principals pobles i ciutats i que deixa enrere vocables grossers que conté la catalana i escull les formes més dolces de pronunciació, amb què, d'aquesta manera, es diferencia del "comú llemosî" i de la de Catalunya, passant a anomenar-se llengua valenciana.

Però, una vegada més, no pot deixar de banda la relació amb el rei Jaume I i les seues gestes -tan importants per a la visió del món medieval d'Escolano-, i també pren partit en aquest tema, atés que diu del rei que, tenint la llengua llemosina com a materna, la preservà fent que tots els repobladors del territori valencià, després de la conquesta, la usaren, malgrat molts d'ells ser aragonesos,

\footnotetext{
De aquí es, que, como nuestro venturoso conquistador el rey don Jayme se huviese criado con ella [...] hizo tanto esfuerço la lengua en él y su casa, que conquistada Valencia [...] quiso que tuviese parte su lengua en la conquista, y que los nuevos pobladores huviesen de usar el Lemosín: no embargante que buena pella del exército fuese de Aragón (pàg. 92-93)
}

Finalment, pel que fa a aquest tema sobre la relació entre el llemosí -entés com la variant antiga del català de la Corona d'Aragó-, i sobre el valencià -entés com la variant contemporània d'Escolano, parlada al regne de València-, s'hi veu realment el propòsit al qual vol arribar Escolano, i apareix així un fragment del capítol on es tracta l'entrada del castellà al territori valencià i la conseqüència que pot tenir aquest fet (Rafanell 1991). Afirma Escolano que la llengua valenciana anava avançant i millorant amb el pas del temps i de les generacions que l'empraven i que li preveia un futur on seria d'igual importància que la castellana. Però, assenyala també que en donar-se la unió de corones d'Aragó i de Castella, anà incorporant-se la llengua castellana al territori valencià i així va fer que el valencià perdé virtuts pel que feia a esplendor, vivacitat i vigència:

\footnotetext{
Se hallava tan adelantada la de Valencia que [...] llegara a los quilates mayores: que puede la que más tiene, como lo ha hecho la castellana de cien años a esta parte [...]. Pero como el imperio de la Corona de Aragón se pasó a la de Castilla, incorporándose las coronas, parece que también se han querido incorporar las lenguas; tanto que entrándose la castellana por los mojones de Valencia, se ha enseñoreado de fuerte gusto de todos, que la natural Valenciana ha ydo afloxando de su vigor, y dexado de pasar adelante en la nobleza. (pàg. 96)
}

Conclou aquest discurs sobre les llengües fent referència a un últim personatge valencià i escriptor, ara d'índole religiosa -terreny de l'autor- com és sant Vicent Ferrer. Així li aprofita per donar caràcter d'apostòlica a la llengua valenciana -tal com venia postulant-se des de l'endemà de la mort de Ferrer (Escartí 2013) - i explica com el sant va anar arreu de tot el món predicant la paraula de Déu en valencià i com l'entenien en tots els llocs, atraient a cristians, moros i jueus,

\footnotetext{
porque si los apóstoles para sembrar la palabra de Dios por el mundo, recibieron en su comisión el don de las lenguas, nuestro gran compatriota, sant Vicente Ferrer, con la valenciana fue entendido de todas las naciones y lenguas del mundo, trayendo con la dulçura d'ella y fuerça de la palabra de Dios, al gremio del christianismo, millares de moros y judios. (pàg. 96)
}

SCRIPTA, Revista internacional de literatura i cultura medieval i moderna, núm. 4 / desembre 2014 / pp. 68 - 79 ISSN: 2340-4841 · doi:10.7203/SCRIPTA.4.4486 
Laura Romà Herèdia. L'interés de Gaspar Escolano per la llengua i la literatura medievals i per Ramon Llull, a la Década primera de la historia de Valencia (1610)

Més enllà de si és cert o no, el fet d'aquesta predicació en català arreu d'Europa, interessa veure com Escolano col labora a enaltir la llengua del país, usant, precisament, el referent medieval de sant Vicent Ferrer, tal com faran, temps a venir -i quasi fins als nostres dies- nombrosos erudits que s'han estimat la nostra llengua (Escartí 2013).

Per concloure aquest punt sobre Escolano i la tradició literària en català, ens cal dir que, si bé el cronista fa un repàs a la tradició literària mitjançant autors importants -tots valencians-, no és pel seu relleu o el de les seues obres, sinó perquè constantment pretén engrandir la seua llengua natural -el valencià-, per tal de denunciar d'alguna manera -sempre sense criticar mai la llengua castellana, la del poder- l'hegemonia de Castella i de la seua llengua en el conjunt de la monarquia hispànica. Per això, Escolano remet als orígens de la llengua, al seu caràcter noble i refinat, al lligam d'aquesta amb els comtes de Barcelona i amb Jaume I i en aquest sentit, destaca la conquesta i repoblament de les terres valencianes, que signifiquen l'acta de naixement del regne de València, i assenyala unes suposades influències sobre els italians -i sobre l'important Petrarca, encara que siga una fal làcia. En el camp de la religió, amb la figura de sant Vicent Ferrer, es veia enriquida la nostra llengua pel fet de comptar amb un sant que la "parlava" arreu d'Europa. Tots aquets exemples citats i que apareixen al capítol esmentat, no són sinó fonaments escollits per Escolano per sostenir la importància de la llengua dels valencians davant la castellana, que cada vegada anava fent-se més present al nostre país durant els segles XVI i XVII (Fuster 1989; Ferrando/Nicolàs 2011).

\section{Ramon Llull a la crònica de Gaspar Escolano, un cas especial}

\subsection{El record de Ramon Llull a la València dels segles ХИЛ $i$ ХИII}

Com és ben sabut, Ramon Llull tenia dos grans objectius entre d'altres, en la seua vida. Per una banda, la còpia manuscrita de les seues obres per a la difusió d'aquestes arreu del món; i d'altra banda, la creació d'escoles on s'expliqués la seua "Art”" (Ramis Barceló, 2012: 62). Aquella preocupació, al remat, fructificarà en una sèrie d'escoles lul listes que arreu de la Corona d'Aragó es varen expandir més enllà de la pròpia vida de Llull. Entre aquestes, té una especial significació la que es va formar a València. És per això que, passem a exposar una panoràmica de l’interés per Llull a la València dels segles XVI i XVII. Però, per poder arribar al nostre objectiu, cal remuntar-nos als orígens de les primeres escoles i l'aparició dels primers moviments lul listes al segle XIV.

De fet, entre els anys 1317 i 1338 sorgeixen a València un seguit d'opuscles anònims o atribuïts a Llull, posteriorment considerats apòcrifs, escrits per deixebles de l'autor, els noms dels quals desconeixem, tret del de Bernat Garí (Domínguez Reboiras 2010: 365), sacerdot de la diòcesi de Mallorca que, a causa de la persecució inquisitorial, s’instal là a València. Garí és autor de De memoria liber o Art memorativa i, segons Josep Perarnau (1985: 85-87), la figura en la qual hem de fixar els inicis del lul lisme valencià. Jordi Pardo, per la seua part, defensa que, 
Laura Romà Herèdia. L'interés de Gaspar Escolano per la llengua i la literatura medievals i per Ramon Llull, a la Década primera de la historia de Valencia (1610)

\begin{abstract}
la primera escuela luliana más mística que doctrinal, se crea en Valencia de manos de franciscanos y fraticelos joaquinistas. Fijada en Alcoi, ésta se convirtió en una escuela de doctrina lulista a cargo de sacerdotes minimi y formada por mercaderes y artesanos de distintos gremios. Sin embargo, desconocemos la manera en que dicho lulismo valentino se fraguó y por qué motivos se centralizó este movimiento luliano en Valencia (Pardo 2001: 117)
\end{abstract}

En qualsevol dels casos, a València i a Alcoi detectarem un evident interés pels ensenyaments de Llull, que arribaven tant a una gran urbs poderosa com a una vila més modesta.

I Garí, juntament amb la resta de documents anònims de l'època, es consideren com les primeres manifestacions de lul lisme a València, que posteriorment influirà en Lleida, Cervera i Barcelona. Però el personatge més representatiu d'aquest lul lisme valencià a Alcoi, del qual també parla Pardo, va ser l'ermità Pere Rossell -segons Amengual, també mallorquí i exiliat a causa de la inquisició, com Garí (Amengual 2011: 44).

A més, un altre personatge relacionat amb el lul lisme a València fou Berenguer de Fluvià, mercader valencià al qual se li concedí un privilegi per part de Pere III d'Aragó, mitjançant el qual se l'autoritzava a ensenyar l'art de Llull, tant a ell com a qui considerara apte per a la tasca. Així, sembla que tant Rossell com Francesc de Llúria -valencià que havia realitzat estudis de medicina lul liana-, s'emparaven sota el privilegi concedit a Fluvià i conformaven aquesta escola. També a Llúria li fou atorgat un privilegi per formar una escola lul lista el 1392 pel rei Joan I i el 1398, Martí l'Humà concedí l'ermita de Miramar a Rossell (Puig i Oliver 1983: 324). Les fortes acusacions d'heretge i les persecucions d'Eimeric contra Rossell, varen obligar a aquest a marxar cap a Roma. Però temps després, i recolzat pels jurats de València, aconseguí la revalidació del privilegi, ara per Joan I, i marxà a ensenyar doctrina lul liana a Cervera (Puig i Oliver 2000: 25-26).

Va ser, doncs, mitjançant estudiants valencians i frares, que el lul lisme arribà a la Universitat de Lleida (Sanahuja 1935: 419-448), i el més destacat lul lià fou el valencià Antoni Riera, batxiller en arts i lleis i contra el qual també va actuar Nicolau Eimeric, una vegada més sense èxit, ja que va haver de retirar-se (Carreras Artau 1943: 18).

Al segle XV les doctrines lul lianes es van institucionalitzar arreu dels territoris de la Corona d'Aragó i el cercle valencià es desplaçà a Catalunya i, en certa mesura, també a Castella, ja que estudiosos com Perarnau defensen la connexió entre el lul lisme valencià i Salamanca, d'interés clarament franciscà (Ramis Barceló 2012, 69-71).

Un fet que demostra l'interés per Ramon Llull és la presència de manuscrits amb obres seues en distintes ciutats, com ara Salamanca, Barcelona, Mallorca o Valènica, que concentraren els estudis lul lians durant el segle XV. Tanmateix, l'escola més important d'aquest període fou la barcelonina, on confluien totes les anteriors, $i$ on un dels més importants mestres va ser el valencià Joan Ros, que posteriorment marxà a Itàlia a ensenyar les doctrines de Llull a Bolonya, Venècia i Pàdua (Batllori 1993, 278-285).

SCRIPTA, Revista internacional de literatura i cultura medieval i moderna, núm. 4 / desembre 2014 / pp. 68 - 79 ISSN: $2340-4841 \cdot$ doi:10.7203/SCRIPTA.4.4486 
Laura Romà Herèdia. L'interés de Gaspar Escolano per la llengua i la literatura medievals i per Ramon Llull, a la Década primera de la historia de Valencia (1610)

Però, la figura més important d'aquest lul lisme del XV fou Pere Daguí, un sacerdot català, autodidacta $\mathrm{i}$ amb grans influències a la cort, fins al punt que va fer que els monarques i el cardenal Cisneros seguiren el lul lisme. Establí les bases de l'Estudi General Lul lià de Mallorca i comptà amb deixebles que difongueren el lul lisme des de València i l'abadia de Montserrat (Ramis Barceló 2012: 75).

D’aquesta manera, el lul lisme valencià ressorgí a la primera dècada del segle XVI, ja que un dels deixebles més importants de Pere Daguí, Jaume Gener, rebé el 1500 un privilegi de mans de Ferran el Catòlic per fundar l'escola lul lista de València, on tingué tres seguidors de gran importància, com eren Bartolomeo Gentile, Joan Bonllavi i Alfonso de Proaza. A més, les obres de Gener influïren en l'escola de Barcelona i d'aquesta manera, també les idees de Pere Daguí (Carreras Artau 1943: 251-256).

Molts autors han defensat la idea que existí una càtedra de lul lisme a València (Pardo 2001: 117), però sembla que les investigacions sobre la institució demostren que no fou així, i no existí una càtedra de lul lisme, sinó mestres lul listes que ensenyaven a les seues escoles (Pérez 1962: 196).

S'ha repetit diverses vegades que Proaza exercí de catedràtic de retòrica a la Universitat de València, de 1507 a 1517, però sembla que no és del tot cert, doncs no figura en la nòmina de catedràtics de la Universitat (Gonzàlez 2003: 469). Ara bé, sabem que fou seleccionat per a inaugurar el curs el 1505 i segurament era professor a dita universitat, però no catedràtic, una idea que trobem, també, en altres autors (Gallego 1980: 250-252).

Proaza fou un humanista, gran amic de Cisneros, que propicià els contactes entre el lul lisme valencià i la Universitat d'Alcalà de Henares i va dur a terme una gran activitat docent i editora a València (Carreras Artau 1943 254-257), publicant les obres de Jaume Gener.

Amb l'ajut econòmic de Gentile, el 1510 començà a publicar nombroses obres lul lianes (Domínguez Reboiras 2010: 375). De la mateixa manera com ho faria Joan Bonllavi, format a València, el qual, servint-se d'aquests contactes establerts per Proaza, fou deixeble dels professors de l'Estudi General de Mallorca (Madurell 1962: 199-200) i, posteriorment, al final de la seua vida, professor a l'escola lul liana barcelonina, via per la qual entrà de nou el lul lisme de Daguí (Madurell 1962: 208-209). És, a més, el primer editor d'un títol de Llull en català: el Blanquerna, el 1521, a València.

Aquella edició del Blanquerna, a més, estava destinada a servir de punt de trencament entre una tradició antiga i medieval -anomenada llemosina-i una tradició literària moderna i actual -valenciana-, que era sentida com quelcom diferent entre els erudits. Fins al punt que Joan Bonllavi i els seus col legues necessitaven adaptar la llengua de Llull al català contemporani seu. Una adaptació que, com sabem de fa temps, va ser realment lleugera (Schmid 1988).

De tota manera, el que interessa remarcar és com, a començaments del segle XVI i encara durant la primera dècada d'aquell segle, les idees lul listes es difonien per València, potser estimulades 
Laura Romà Herèdia. L'interés de Gaspar Escolano per la llengua i la literatura medievals i per Ramon Llull, a la Década primera de la bistoria de Valencia (1610)

pels desitjats canvis socials que reclamaven els agermanats i tenint en compte el referefons de reformador de la societat que podem detectar en Llull.

Tanmateix, un dels moments principals per a la tradició lul liana del segle XVI es deu a les sessions que tingueren lloc el 17 i el 18 de juny de 1562, quan el teòleg Joan Lluís Vileta acudí al Concili de Trento acompanyant el bisbe de Barcelona, Guillem Caçador, i aconseguí salvar l'obra de Llull de l'índex d'obres prohibides on havia estat inclosa pel papa Pau IV, el 1559.

Els estudis realitzats per diferents investigadors ens mostren com d'irregular i variable fou la configuració d'un pla d'estudis generals a València, principalment pels entrebancs i disputes entre els seguidors del nominalisme -que es nodrien de les influències arribades des de la Universitat de París- i els seguidors del realisme -que eren els tomistes, seguidors de les idees de sant Tomàs d'Aquino. Fra Gallego ens diu que:
el grupo lulista de Valencia, marginado de la vida universitaria trabajó desde la creación de ésta en la oposición, a favor de una reforma en la que cupieran todas las corrientes de pensamiento. La amplitud de horizontes que ofrecía el movimiento nominalista movió a los lulistas valencianos a incorporarse a la lucha en pro de la implantación de éste en el Estudio General, como posibilidad de incorporarse ellos a la vida universitaria. (Gallego 1980: 251)

Així, per a Gallego, l'únic catedràtic lul lista de la Universitat de València fou el mallorquí Pere d'Oleza i Rovira, que ocupà la càtedra de medicina el curs de 1514 i formà part dels inicis de l'escola lul liana de València (Gallego 1980: 252). Tanmateix, no ens ha arribat documentació que ens confirme el vincle d'Olesa amb l'escola valenciana, però si de la presència d'un altre personatge del mateix cognom, relacionat amb el cercle lul lista valencià: Jaume Olesa i Sanglada (Ensenyat 2003: 585-586).

Amb tot, podem relacionar el lul lisme amb la Universitat de València, però no disposem de cap testimoni fiable que ens confirme l'existència d'una càtedra lul liana o d'un catedràtic lul lià. Per altra banda, sembla que l'escola lul lista valenciana gaudia d'independència respecte a la Universitat i que es tractava d'un cercle d'humanistes dirigits per Gener (Barceló 2012: 78). El lul lisme valencià tingué influències i continuïtat a les escoles de Barcelona, Alcalà i Mallorca, però també a Itàlia, ja que Bartolomé Gentile, estudiant en contacte amb els cercles de Barcelona i València va retornar a la seua terra natal, Gènova, on el propagà (Batllori 1993: 299-303).

Gràcies a aquest ràpid recorregut pel lul lisme a la València del segle XVI podem entendre com la figura de Ramon Llull arribà a interessar a un erudit com Gaspar Escolano, i d'aquest aspecte parlarem tot seguit. Però abans voldríem assenyalar com, el segle XVI, que en certa manera és considerat el segle de Llull (Ruiz Simon 1994:113-116), pot veure's així sobretot a Europa on erudits prestigiosos de l'època, com Descartes, Kircher, Comenius i d'altres prenen interés per l'obra de l'autor mallorquí, mentre que en terres hispàniques queda replegat sobretot a Mallorca i a l'ordre franciscana (Carreras Artau 1943: 271), atés que és l'època en què el lul lisme serà considerat heretge i, amb la mort de Felip II, condemnat amb més fermesa per la Inquisició. 
Laura Romà Herèdia. L'interés de Gaspar Escolano per la llengua i la literatura medievals i per Ramon Llull, a la Década primera de la historia de Valencia (1610)

Certament, la sospita d'heretgia sobre els pensaments de Llull no era res nou. L'inquisidor Eimeric, al segle XV, s'havia encarregat de fomentar-la -segurament per causa de lectura defectuosa dels manuscrits lul lians-, però aquella sospita s'havia vist informada, com hem vist, quan al Concili de Trento el papa havia inclòs les obres del mallorquí entre les prohibides. Ara bé, gràcies a Vileta, Llull no havia estat condemnat per sempre més a l'“infern". Tanmateix, les polèmiques entre els àmbits dominicans i franciscans -en els espais universitaris i en altres- degueren mantenir una certa sospita sobre les idees de Llull. A finals del segle XVI i a començaments del XVII, Gaspar Escolano en serà una mostra interessant d'aquelles creences.

\subsection{La visió de Gaspar Escolano sobre Ramon Llull}

En aquest apartat passem a exposar la visió de Ramon Llull que ens mostra Gaspar Escolano a la seva crònica, concretament als capítols XIX, XX, XXI i XXII (pàg 616-652) del tercer llibre de la Década primera de la historia de la insigne y coronada ciudad y Reino de Valencia (1610).

Primerament, Escolano assenyala els interessos que l'impulsen a incloure Llull dins la crònica,

La causa de Ramon Llull, natural de la ciudad de Mallorca, que se tocó en el capítulo pasado, es común a la de Valencia. Lo primero por la mucha vezindad y correspondencia que entre sí tienen. Lo segundo, por haver seguido en tiempos pasados el pleyto de su inocencia y ciencia hasta la corte del Papa [...] un sacerdote valenciano, llamado mosén Antonio Riera, Licenciado en ambos derechos. Tercero, por haver cáthedra fundada en su dotrina en nuestra universidad. Y finalmente, porque un moderno dexó cargado en su libro el nombre de los doctos curas de Valencia, con una relación que dize la tomó de fray Nicolas Eymerique (618).

Tot seguit ens presenta l'inquisidor Nicolau Eimeric i ens explica com aquest va trobar entre els escrits de Llull símptomes d'heretgia i la carta que escriu al papa Gregori XI perquè els condemnara. Així com també la resposta del papa (118-120). De fet, el procés d'Eimeric contra Llull ja ha estat estudiat en divereses ocasions (Roura 1995).

Escolano, però, ens explica com, arran de la butlla papal, la figura i la doctrina de Ramón Llull es veieren menyspreades i com, malgrat això, seguien havent seguidors incondicionals de l'autor mallorquí que defensaven la seua innocència i santedat i pretenien divulgar la seua «Art» a través de la creació d'escoles, per a les quals necessitaven privilegis -com hem vist en l'apartat anterior- que els eren concedits (620-622).

Ens parla de com Joan Seguí, penitenciari i canonge de Mallorca, al seu llibre De la vida y hechos de Ramón Llull, publicat el 1606, tracta el tema de la butlla papal contra Ramon Llull, defensant la idea que Emireic la inventà.

De la mateixa manera, els seguidors de Llull encetaren un procés per demostrar la falsedat de la butlla i la primera raó que ho demostrava era que no es trobava als registres de la cúria Romana on es troben recollides totes les butlles i sobretot les de Gregori XI. Destaca la importància del 
Laura Romà Herèdia. L'interés de Gaspar Escolano per la llengua i la literatura medievals i per Ramon Llull, a la Década primera de la bistoria de Valencia (1610)

valencià mossèn Antoni Riera que, des d'Avinyò, seguí el procés en què Eimeric fou citat, l'any 1395, davant el cardenal Leonardo, nomenat pel papa Benet XIII, i on se l'acusava de falsificar dita butlla papal, amb la prova de no aparéixer als registres del pontífex. A més de l'acusació directa de Riera a Eimeric, afirmant que si la butlla fos escrita realment pel papa no tenia cap veracitat, car les heretgies assenyalades per Eimeric no es trobaven en cap dels vint llibres acusats i, a més, els fragments citats no coincidien amb els originals de Llull, que sembla que havien estat manipulats.

Un dels moments més destacats, i al qual també fa referència Escolano, és al Concili de Trento, quan Joan Vileta aconseguí extraure els llibres de Llull del catàleg d'obres prohibides del papa Pau IV.

Quant a la figura de Ramon Llull, Escolano es limita a recrear la seua vida, la seua biografia a través de fonts com l'obra de Joan Seguí, Vida y hechos del admirable Dotor y Martyr Ramon Lull, vezino de Mallorca, que havía vist la llum pocs anys abans (1606) i de la qual ens diu que és la millor en aquest camp.

Centrant-nos ara en el tema que ens ocupa, cal dir que Escolano no deixa massa al descobert la seua opinió quant a la polèmica incitada per Eimeric cap al mallorquí i la seua obra, i tampoc no es posiciona clarament, ni a favor ni en contra. Tanmateix trobem algunes mostres subjectives que poden donar-nos certs indicis sobre la vertadera postura adoptada per Escolano respecte al tema.

Per exemple, podem trobar, com l'autor ens diu:

creería yo que toda la lite topa, en que los libros de Ramón Lull no fueron bien entendidos,
por la dificultad de sus términos: y que todos devemos suspender el juyzio y aguardar el de la
Santa Madre Iglesia, ante quien se está ventilando y examinando la causa. De aquí es que por
los buenos ojos con que devemos mirar al dicho Nicolás Eymerique, me persuado a que no
será suya una relación, que dize un moderno haverla tomado de un libro no impreso, y que
tiene el nombre de fray Eymerique (pàg. (331).

Observem aleshores com en certa manera Escolano tracta de defensar Eimeric o, almenys, apartarlo d'un judici popular i, deixant-ho a mans de l'església, no ho mostra descaradament però si podem sospitar certa empatia cap a l'inquisidor. Però, no sols això, sinó que, si els llibres de Llull no foren ben entesos per Eimeric, val tant com dir que les idees lul lianes no eren herètiques, a parer del cronista valencià.

De manera que, Escolano, fent una exhibició d'imparcialitat, tot i que deixa anar algunes idees contra Llull o contra Eimeric, a la fi aparenta una neutralitat que, malgrat que potser no la senta, era ben recomanable de cara a possibles problemes amb la poderosa Inquisició. En certa manera, Escolano practicarà, així, una evident autocensura.

Per últim, vegem com Escolano sembla traspassar el paper de l'opinió personal als lectors de la crònica, ja que, com ja hem esmentat, no opta per decantar-se clarament cap a ninguna de les posicions, ni per la d'Eimeric i els seus seguidors, ni per la dels lul listes, sinó que, com reflecteix en l'últim paràgraf referit a Llull, prefereix mantenir-se al marge, deixant la decisió a mans de qui realment exerceix el poder.

SCRIPTA, Revista internacional de literatura i cultura medieval i moderna, núm. 4 / desembre 2014 / pp. 68 - 79 ISSN: $2340-4841 \cdot$ doi:10.7203/SCRIPTA.4.4486 
Laura Romà Herèdia. L'interés de Gaspar Escolano per la llengua i la literatura medievals i per Ramon Llull, a la Década primera de la historia de Valencia (1610)

\begin{abstract}
De todo el processo désta vida del Doctor Ramón Lull y de la tragedia que tenemos relatada que pasó con fray Nicolás Eymerique, puede, el que quisiere, hazer consequencias y dar sentencia. Más yo lo reservo todo para la Sede Apostolica, cuyo es decidir proposiciones y canonizar santos. (pàg. 650)
\end{abstract}

\title{
5. Conclusió
}

La lectura atenta de l'obra d'Escolano ens ha permés veure com, aquest autor, a través de la seua Década primera -un clàssic de la historiografia valenciana dels segles XVI-XVII-, es mirava el passat medieval del regne de València i, en especial, la seua llengua i alguns dels autors més emblemàtics, als quals dedica una atenció molt diversa. Jaume I, Ausiàs March, Jaume Roig, però també Jordi de Sant Jordi, Andreu Febrer i, sobretot, Ramon Llull, atrauen la seua atenció, per diferents motius.

En primer lloc, alguns d'aquests noms li aprofitaran per destacar la suposada «primacia» de la llengua pròpia dels valencians, per damunt de qualsevol altra i, en especial, per defensar-se del castellà que, tanmateix, Escolano no s'està d'usar sempre, col laborant, així, a augmentar la seua difusió.

Seguint idees més o menys ajustades a una realitat -la realitat que podien entendre els homes del barroc-, Escolano fa derivar el "valencià" del seu temps, de la llengua parlada a València pel rei Jaume I i pels conquistadors catalans, però, alhora, vol fer veure que el català provindria d'un suposat "llemosí" que, originat a la terra de la llavors poderosa França, tindria un component important aportat pels parlants "hispànics" que, rere la invasió musulmana, s'havien desplaçat al nord, per preservar la seua fe cristiana.

La llengua, arribada a la fi a València, serà ací on s'ha perfeccionat, donant matèria excel lent en autors importants, com els ja citats.

Un cas a banda serà el de Llull. Al filòsof mallorquí, Escolano dedica diferents capítols. No tant com un altre «llemosí», sinó perquè al seu temps, la figura de Llull havia esdevingut de moda, després de la polèmica del Concili de Trento que, havia revitalitzat les antigues teories de l'inquisidor Eimeric de la fi del segle XIV.

Escolano, home de formació relativament humanista i amb una imatge de persona assenyada -com hem pogut descobrir al tractat breu de la seua biografia que hem redactat-, lluny d'atacar Llull o Eimeric, intenta mantenir-se neutral $i$, a tot cas, presentarà una autocensura que vindrà imposada, segurament, pel temor a la Inquisició.

Però, què amaga realment Escolano? Ja siga per por a la Inquisició o pel simple fet d'ocupar un lloc destacat com a religiós en l'època, potser ens amaga algunes dades respecte a Eimeric que podrien menyscabar la imatge de l’inquisidor. 
Laura Romà Herèdia. L'interés de Gaspar Escolano per la llengua i la literatura medievals i per Ramon Llull, a la Década primera de la historia de Valencia (1610)

En llegir obres i estudis en referència a dita polèmica, com l'estudi i edició de Jaume de Puig i Oliver de l'obra Dialogus contra lulistas de Nicolau Eimeric, podem aprofundir una mica més en el rerefons i les intencions reals de l'inquisidor, que no acaba de mostrar-nos l'obra d'Escolano. Si bé el cronista es fa ressò de la butlla papal -emesa suposadament a mans del papa Gregori XI-, que condemnava per heretge l'obra del mallorquí, i del posterior desemmascarament de la manipulació exercida per l'inquisidor sobre els textos de Llull, no ens parla en cap moment del motiu que impulsà a Eimeric a emprendre aquesta lluita constant contra Llull. Però, com ja hem esmentat abans, seguint estudis i obres com El "dialogus contra lullistas" de Nicolau Eimeric. Edició $i$ Estudi de J. de Puig o Nicolan Eimeric (1320-1399) i la polèmica inquisitorial de Josep Brugada, descobrim com a Nicolau Eimeric, el càrrec d'inquisidor general -el qual Pere III pretenia treure-li- li havia aportat entre altres coses un gran nombre d'enemics, entre els quals es trobava el monarca. Aquesta enemistat va anar agreujant-se quan, el 1366, Eimeric es va decidir a encetar l'atac contra les obres de Llull i perseguir els seus seguidors. Pere IV va prohibir l'inquisidor que predicara a Barcelona -cosa que incomplí- i el desterrà. Tanmateix, poc abans de la mort del Cerimoniós, el 1387, el seu fill Joan I reconeixia la legitimitat del papa d'Avinyó, cosa que provocà la tornada al càrrec d'inquisidor general a Eimeric. Ara, era l'ocasió i l'inquisidor no va perdre el temps. Una vegada recol locat al costat de la corona i amb influències sobre la cúria, començà de nou i amb més força la seua tasca antilul liana, provocant l'emissió de la butlla papal i la condemna i prohibició de les obres de Llull per heretgia. Havia aconseguit el que pretenia.

Eimeric, en un primer moment, triomfa i el lul lisme s'ha de veure relegat a la clandestinitat, fins que des de València, un grup de lul listes encapçalats per Pere Rossell aconsegueix fer front a l'inquisidor i acaba derrotant-lo i acusant-lo de manipulació, provocant el seu desterrament definitiu.

Per tant, ara podem preguntar-nos per què Escolano no es fa ressò a la seua crònica dels inicis d'Eimeric en la seua lluita contra Llull, potser provocada simplement pel seu afany censurador com a inquisidor i segurament, condicionada per l'enemistat i ganes de revenja amb el Cerimoniós. Al remat, s'ha pogut comprovar com Escolano tracta minuciosament la polèmica de Llull, intentant evitar alhora, mitjançat l'omissió de dades fonamentals, menysprear la figura de Nicolau Eimeric. 
Laura Romà Herèdia. L'interés de Gaspar Escolano per la llengua i la literatura medievals i per Ramon Llull, a la Década primera de la historia de Valencia (1610)

\section{Bibliografia}

Amengual, Josep (2011) El bisbe ermità de Miramar. Jaume Badia, exponent del lu lisme mallorquí del segle xiv, Palma, Publicacions del CETEM.

Batllori, Miquel (1993) Ramon Llull i el Lul tisme. Obra completa II, València, ed. Tres i Quatre.

Belenguer, Ernest (2009) Jaume i a través de la història, Publicacions de la Universitat de València [1a ed., 1984].

Brugada, Josep (1998) «Nicolau Eimeric (1320-1399) i la polèmica inquisitorial», Barcelona, Rafael Dalmau

Carreras Artau, Joaquim i Tomàs (1943), História de la filosofía española. Filosofia cristiana de los siglos XIII al XV, Madrid, Real Academia de Ciencias Exactas, Físicas y Naturales.

Domínguez Reboiras, Fernando (2010), «La percepción del pensamiento luliano en la península ibérica hasta el siglo XIX. Un intento de síntesis”, Revista de Lenguas y Literatura Catalana Gallega y Vasca, 15, pp. 361-385.

Duran, Eulàlia (1991), «Defensa de la pròpia tradició davant d'Itàlia al segle xvi», Miscel tània Joan Fuster, Barcelona, Publicacions de l'Abadia de Montserrat, vol. 3, pp. 241-265.

Ensenyat, Gabriel (2012), «L'activitat lul liana a la Mallorca del segle xiv: un lul lisme amagat?», Jornades lul bianes en homenatge a Jocelyn N. Hillgarth i Anthony Bonner, Palma, Edicions de la Universitat de les Illes Balears, pp. 99-127.

Escartí, Vicent Josep (1997), La primera edició valenciana de l'obra d'Ausiàs March (1539), València, Fundació Bancaixa.

—. (1998), Pere Antoni Beuter, Primera Part de la Història de València, València, Publicacions de la Universitat de València.

—_. (2009), Jaume Bleda i l'expulsió dels moriscos valencians, València, Fundació Bancaixa.

—. (2012), "Jaume I, el Llibre dels feits i l'humanisme: un model "valencià" per al cesarisme hispànic", eHumanista/IVTTRA, 1, pp. 128-140.

. (2013) “El record de sant Vicent Ferrer durant l'Edat Moderna (ss. XVI-XVIII), dins Bellveser, R. (ed.) Els valencians en el Compromís de Casp i en el Cisma d'Occident, València, Institució Alfons el Magnànim, pp. 382-424.

Escolano, Gaspar (1610), Década primera de la historia de la insigne i coronada ciudad y reino de Valencia, València, ed. Pere Patrici Mey.

Febrer, Andreu (1951), Poesies, a cura de M. de Riquer, Barcelona, Barcino.

Ferrando, Antoni (1983), Els certàmens poètics valencians, València, Institució Alfons el Magnànim.

Ferrando, Antoni i Nicolás, Miquel (2011) Història de la llengua catalana, Barcelona, UOC. 
Laura Romà Herèdia. L'interés de Gaspar Escolano per la llengua i la literatura medievals i per Ramon Llull, a la Década primera de la historia de Valencia (1610)

Fuster, Joan (1989), «Notes sobre el "llemosî" a la València del segle XVI», Llibres i problemes del Renaixement, València - Barcelona, Institut de Filologia Valenciana - Publicacions de l'Abadia de Montserrat, pp. 43-63.

Gallego, Jordán (1980), «La Facultad de artes de la Universidad de Valencia desde 1500 hasta 1525» Escritos del vedat, 5, pp. 81-132.

González, Enrique (2003), «Lectores públicos i privados en la universidad de Valencia (1499-1520)» en Aulas i saberes, vi Congreso internacional de historia de las universidades hispánicas, València, Universitat de València, pp. 460-520.

Madurell, Jose Maria (1962), «La escuela de Ramón Llull de Barcelona; sus alumnos, lectores y protectores», Estudios Lulianos, vi.

Maravall, Jose Antonio (1981), La cultura del Barroco, Barcelona, Ariel.

Martí Grajales, Francesc (1892), El doctor Gaspar Juan Escolano, Cronista del reino, València, ed. Francisco Vives Mora.

Pardo Pastor, Jordi (2001), «El lulismo hispánico del trescientos» en Ramon Llull: caballero de la fe. El arte luliana y su proyección en la Edad Media, Pamplona, Universidad de Navarra, pp. 119-129.

Perarnau, Josep (1985), «El lul lisme de Mallorca a través de València. Edició de l’Art abreujada de confessió», Arxiu de textos Catalans Antics, 4, pp.61-172.

Pérez, Lorenzo (1962), «La causa luliana en Roma durante el reinado de Felipe ii», Anthologica Annua, 13.

Petrarca, Francesco (1989), Cancionero. Ed. Jacobo Cortines; versió italiana G. Contini; intro. Nicholas Mann, Madrid, Cátedra.

Puig, Jaume de (1983), «Documents inèdits referents a Eimeric i al lul lisme», Arxiu de textos catalans antics, 2, pp. 319-346.

—. «El «Dialogus contra lulistas», de Nicolau Eimeric, O.P. Edició i estudi», Arxiu de textos catalans antics, 19, pp. 7-296.

Rafanell Vall-llosera, August (1991), «El llemosinisme valencià a la darreria del segle XIX», Caplletra, 11, pp 35-50.

Ramis Barceló, Rafael (2012), Un esbozo cartográfico del lulismo universitario y escolar en los reinos hispánicos, Palma, Universitat de les Illes Balears.

Riquer, Martí de / Badia, L. (1984), Les poesies de Jordi de Sant Jordi, cavaller valencià del segle xv, València, ed. Tres i Quatre.

Roura Roca, Jaime (1959), Posición doctrinal de Fr. Nicolás Eymerich en la polémica luliana, Diputación Provincial, Girona.

Ruiz Simón, Josep Maria (1994), El segle xvii, el segle de Llull, Revista Enrahonar, 22.

SCRIPTA, Revista internacional de literatura i cultura medieval i moderna, núm. 4 / desembre 2014 / pp. 68 - 79 
Laura Romà Herèdia. L'interés de Gaspar Escolano per la llengua i la literatura medievals i per Ramon Llull, a la Década primera de la historia de Valencia (1610)

Sanahuja, Pedro (1935), La enseñanza de la teología en Lérida. Cátedras regentadas por maestros franciscanos (siglos XIV-XV)», Archivo Ibero-Americano, 38, pp. 419-448.

Seguí, Joan (1606), Vida y hechos del admirable Dotor y Martyr Ramon Lull vezino de Mallorca, Palma de Mallorca, ed. per Gabriel Guasp.

Schmid, Beatrice (1988), Les "Traduccions valencianes" del Blanquerna (València 1521) i de la Scala Dei (Barcelona 1523), Barcelona, Curial Edicions.

Valda, Joan Baptista de (1998) Llibre de les assitències i funccions, a cura de V. J. Escartí i A. López Quiles, València, Ajuntament de València.

Viciano, Pau (2000), “L’edat mitjana en la crònica de Gaspar Escolano”, Recerques, 40, pp. 135150.

SCRIPTA, Revista internacional de literatura i cultura medieval i moderna, núm. 4 / desembre 2014 / pp. 68 - 79 